\title{
Pemanfaatan Kantong Plastik Bekas Untuk Paving Block
}

\author{
${ }^{1}$ Guntar Marolop S. dan ${ }^{2}$ Suhendra \\ ${ }^{1}$ Dosen Prodi Teknik Lingkungan Universitas Batanghari, Jambi \\ ${ }^{2}$ Dosen Prodi Teknik Sipil Universitas Batanghari, Jambi
}

\begin{abstract}
Abstrak. Salah satu produk teknologi adalah plastik. Plastik banyak digunakan sebagai perabot rumah tangga, sebagai pembungkus kemasan (kantong) dan penggunaan lain. Selain fungsinya yang praktis dan desain kemasan yang menarik, harga plastik juga lebih murah sehingga banyak digemari oleh masyarakat. Pada umumnya kantong plastik hanya digunakan sekali pakai dan akan dibuang berupa sampah. Sampah kantong plastik ini sulit terurai dan memiliki komponen pencemar yakni benzena yang merupakan salah satu penyebab kanker. Bila jumlah sampah kantong plastik semakin banyak, maka sampah ini akan menimbulkan masalah bagi lingkungan dan kesehatan. Di sisi lain, sampah plastik masih dapat dimanfaatkan melalui proses tertentu, salah satu diantaranya mengolah kantong palstik menjadi paving block. Dengan cara mencairkan sampah kantong plastik melalui proses pemanasan. Penelitian yang dilakukan dengan mencairkan bermacam bentuk dan jenis sampah plastik, kemudian dicetak menjadi paving block, membutuhkan sekitar 26 liter sampah plastik untuk mendapatkan satu buah paving block tipe segi enam dengan tebal $5 \mathrm{~cm}$. Hasil uji kuat tekan menunjukkan bahwa mutu yang dihasilkan memenuhi klasifikasi mutu D : bisa digunakan untuk taman dan penggunaan lain.
\end{abstract}

Kata Kunci: Sampah Kantong Plastik, Paving block, kuat tekan

\section{PENDAHULUAN}

Menurut UU RI No.18/2008 Tentang Pengelolaan Sampah, sampah adalah sisa kegiatan sehari-hari manusia dan/proses alam yang berbentuk padat. Semakin banyaknya dan semakin bervariasinya kegiatan manusia maka semakin banyak jumlah sampah yang dihasilkan.

Berdasarkan pengelolaannya maka jenis sampah dibagi 3 jenis yaitu :

a. Sampah organik: sampah yang terdiri dari bahan-bahan yang bisa terurai secara alamiah/biologis, seperti sisa makanan dan guguran daun. Sampah jenis ini juga biasa disebut sampah basah.

b. Sampah anorganik: sampah yang terdiri dari bahan-bahan yang sulit terurai secara biologis. Proses penghancurannya membutuhkan penanganan lebih lanjut di tempat khusus, misalnya plastik, kaleng dan styrofoam. Sampah jenis ini juga biasa disebut sampah kering.

c. Sampah bahan berbahaya dan beracun (B3): limbah dari bahan-bahan berbahaya dan beracun seperti limbah rumah sakit, limbah pabrik dan lain-lain.

Setiap jenis sampah seperti disebutkan di atas berbeda-beda waktu penguraiannya berubah menjadi tanah. Sampah yang mudah terurai adalah sampah organic. Sampah anorganik lebih sulit mengurai disbanding dengan sampah organic. Demikian juha sampah kantong plastik yang merupakan bagian dari sampah anorganik, membutuhkan waktu yang lama untuk terurai kembali menjadi tanah.

Berikut ini disajikan data lama waktu penguraian beberapa jenis sampah anorganik seperti Tabel 1.

Tabel 1. Waktu penguraian beberapa jenis sampah

\begin{tabular}{|c|c|c|}
\hline No & Jenis sampah & Lama penguraian \\
\hline 01 & Kertas & $2-5$ bulan \\
\hline 02 & Kulit buah & 6 bulan \\
\hline 03 & Kardus / Karton & 5 bulan \\
\hline 04 & Filter rokok & 10-12 tahun \\
\hline 05 & Kantong plastik & 10-12 tahun \\
\hline 06 & Benda-benda kulit & 25-40 tahun \\
\hline 07 & Kain Nilon & 30-40 tahun \\
\hline 08 & Jaring ikan & 30-40 tahun \\
\hline 09 & Plastik & 50-80 tahun \\
\hline 10 & Botol plastik & tidak dapat diperkirakan waktu hancurnya \\
\hline 11 & Styrofoam & tidak dapat hancur \\
\hline
\end{tabular}


Jika dilihat dari data di atas, terurainya sampah kantong plastik mencapai (10-12) tahun. Kantong plastik akan terletak di tanah dalam waktu lama sehingga berpotensi untuk mencemari tanah, air dan udara. Disamping itu, plastik juga berperan menjadi tempat berkembangbika dan tempat berteduhnya vektor penyakit.

Sebelum diberlakukannya UU RI No.18/2008 Tentang Pengelolaan Sampah, sampah yang dihasilkan manusia dikelola dengan cara menumpuk dan selanjutnya dibuang ke lingkungan. Selanjutnya dalam UU RI No.18/2008, sampah yang dihasilkan manusia harus dikelola. Menurut UU RI No.18/2008, pengelolaan sampah yang dimaksud adalah berbasis konsep pengelolaan sampah paradigma baru. Konsep pengelolaan sampah paradigma baru diwujudnyatakan melalui dua upaya yaitu :

a. Upaya pengurangan sampah

b. Upaya penangganan sampah.

Upaya pengurangan sampah adalah suatu nentuk tindakan untuk mengurangi pemakaian plastik di sumber sampah.

Upaya penanganan sampah dimaksud adalah upaya untuk memanfaatkan sampah, karena sampah masih memiliki sumber daya. Salah satu upaya, adalah mmemanfaatkan sampah untuk berbagai keperluan.

Dengan cara mengubah sampah plastik menjadi benda bermanfaat pada manusia, maka volume sampah kantong plastic sebagai bahan pencemar akan semakin berkurang. Semakin banyak sampah plastik yang diolah, semakin sedikit jumlah sampah kantong plastik di sumber sampah atau di tempat pemrosesan akhir sampah sebagai bahan pencemar dan selanjutnya akan berpengaruh terhadap semakin minimalnya pencemaran lingkungan.

Paving block adalah suatu komposisi bahan bangunan yang dibuat dari campuran semen Portland atau bahan perekat hidrolis sejenisnya, air dan agregat dengan atau tanpa bahan tambahan lainnya yang tidak mengurangi mutu bata beton itu (SNI 03-0691-1996).

Paving block sering dijumpai sebagai perkerasan jalan, pelataran parkir atau pelataran halaman untuk rumah maupun gedung pemerintahan. Namun, paving block yang nila kuat tekannya di bawah SNI 030691-1996 juga dapat dipergunakan untuk keperluan lain, misalnya untuk memperindah taman kota dan lain sebagainya.

Untuk mengolah sampah kantong plastik menjadi paving block, sampah kantong plastik dilelehkan sampai mencair. Selanjutnya plastik cair tersebut dituangkan ke dalam cetakan paving block dan didiamkan selama beberapa waktu hingga suhunya menurun. Seiring dengan penurunan suhu maka plastik cair di dalam cetakan paving block tersebut akan mengering dan mengeras. Untuk mengetahui nilai kuat tekan paving block, maka dilakukan uji kuat tekan terhadap paving block.

Kuat tekan dihitung dengan rumus :

Kuat tekan $=($ Beban tekan $) /($ Luas bidang tekan $)$

$\mathrm{K} \quad=\mathrm{P} / \mathrm{L}\left(\mathrm{kg} / \mathrm{cm}^{2}\right)$

Nilai kuat tekan paving block untuk berbagai keperluan adalah seperti tertera pada Tabel 2.

Tabel 2. Nilai Kuat Tekan

\begin{tabular}{cccc}
\hline No & Nilai kuat tekan (MPa) & Kelas Mutu & Keterangan \\
\hline 01 & $35-40$ & A & Untuk jalan \\
02 & $17,0-20$ & B & Untuk pelataran parkir \\
03 & $12,5-15$ & $\mathrm{C}$ & Untuk pejalan kaki \\
04 & $8,5-10$ & $\mathrm{D}$ & Untuk taman dan penggunaan lain. \\
\hline
\end{tabular}

Sumber : SNI 03-0691-1996

\section{METODE PENELITIAN}

Menurut penggunaannya, penelitian ini termasuk dalam penelitian terapan, yaitu penelitian yang bertujuan untuk meningkatkan pengetahuan ilmiah dengan suatu tujuan praktis. Hasilnya dapat segera dipakai untuk keperluan tertentu/praktis. Penelitian ini dilakukan melalui beberapa tahapan dan dilakukan secara sistematis serta mengikuti konsep.

Waktu penelitian direncanakan selama 3 bulan 3 minggu. Tempat pelaksanaannya dibagi di dua tempat. Pembuatan paving block dilaksanakan di Jln Walisongo Rt 03 Blok II No 96 Kel. Kenali Besar Kec. 
Alam Barajo Kota Jambi. Uji kuat tekan paving block dilakukan di Laboratorium Teknik Universitas Batanghari.

Data yang dibutuhkan dalam penelitian ini adalah data data primer. Data dimaksud adalah : 1).Berat dan volume sampah kantong plastic untuk paving block; 2). Berat paving block; 3). Kuat tekan paving block dari Laboratorium. Data sekunder meliputi besaran kuat tekan paving block sesuai SNI 03-0691-1991

Peralatan yang digunakan adalah :

1. Timbangan untuk mengukur berat sampah dan kotak sampah sebagai pengukur volume sampah dan alat tulis

2. Mistar penggaris untuk mengukur sisi-sisi dan tebal paving block.

3. Kompor gas sebagai sumber panas

4. Wadah tempat sampah plastik dipanaskan

5. Cetakan paving block ukuran 9 centimeter x 9 centimeter, ketebalan : 5 centimeter.

6. Alat uji tekan uniaksial.

Adapun Langkah-langkah pelaksanaan pembuatan benda uji penelitian Sebagai berikut:

1. Timbang berat dan ukur volume sampah yang akan diolah.

2. Lebur sampah kantong plastik di atas kompor sambil diaduk sampai mencair.

3. Sampah yang sudah mencair, masukkan ke dalam cetakan yang sudah tersedia.

4. Dinginkan (tunggu) selama 2 jam sampai plastik cair membeku dalam cetakan paving block .

5. Timbang berat paving block.

6. Lakukan uji tekan

\section{HASIL DAN PEMBAHASAN}

Hasil penelitian menunjukkan jika untuk pembuatan satu buah paving block bentuk segi enam dengan tebal $5 \mathrm{~cm}$ membutuhkan bahan sebagaimana tertera dalam tabel 3.

Tabel 3. Kebutuhan Sampah Kantong Plastik untuk paving block

\begin{tabular}{ccccc}
\hline Bentuk Paving block & $\begin{array}{c}\text { Berat sampah kantong plastik } \\
\text { (gram) }\end{array}$ & $\begin{array}{c}\text { Luas bidang tekan } \\
\left(\mathrm{cm}^{2}\right)\end{array}$ & $\begin{array}{c}\text { Volume Paving } \\
\text { block }\left(\mathrm{cm}^{3}\right)\end{array}$ & $\begin{array}{c}\text { Volume sampah plastik } \\
\left(\mathrm{cm}^{3}\right)\end{array}$ \\
\hline Segi enam & 1100 & 235,775 & 1178,875 & 26000 \\
\hline
\end{tabular}

Sumber : Hasil penelitian, 2019.

Adapun hasil uji kuat tekan yang dilakukan pada tanggal 13 September 2019 adalah seperti Tabel 4.

Tabel 4. Hasil Uji Kuat Tekan Paving Block Sampah Kantong Plastik

\begin{tabular}{ccccc}
\hline Bentuk Paving block & Berat $(\mathrm{gram})$ & Density $\left(\mathrm{grm} / \mathrm{cm}^{3}\right)$ & Luas bidang tekan $\left(\mathrm{cm}^{2}\right)$ & $\mathrm{Kuat} \mathrm{Tekan}\left(\mathrm{Kg} / \mathrm{cm}^{2}\right)$ \\
\hline Segi enam & 1.086 & 0,709 & 235,775 & 98,90
\end{tabular}

Sumber : Laboratorium Teknik Universitas Batanghari, Sept.2019.

Hasil uji tekan paving block sebesar 98,90 kg/ $\mathrm{cm}^{2}$. Menurut SNI 03-0691-1996 mengatakan bahwa paving block dengan kuat tekan $98,90 \mathrm{~kg} / \mathrm{cm}^{2}$ dapat digunakan pada taman kota.

Berat paving block adalah 1086 gram, sedangkan berat sampah kantong plastik sebelum dicetak sebesar 1100 gram dan volumenya sebanyak 26 liter. Namun sampah kantong plastiknya tidak sejenis, tetapi ada ukuran besar ada ukuran kecil. Demikian juga berat per kantong plastik bervariasi.

\section{SIMPULAN}

1. Berat dan volume sampah kantong plastik yang diperlukan untuk membuat 1 (satu) paving block ukuran adalah :

Berat sampah $=1.110$ gram dan volume $=26$ liter atau $26.000 \mathrm{~cm}^{3}$

2. Kuat tekan paving block hanya sebesar $98,90 \mathrm{~kg} / \mathrm{cm}^{2}$, dan dapat digunakan untuk taman kota.

\section{Saran}

Pembuatan paving block dengan bahan baku plastik hendaknya ditingkatkan untuk meminimalisir sampah plastik diperkotaan. Paving block hasilnya dapat digunakan untuk variasi keindahan taman kota. 


\section{DAFTAR PUSTAKA}

B. Pamungkas, 2007, Kuat Tekan Paving Block Metode Mekanis, Eprints Universitas Diponegoro, Semarang.

Enri Damanhuri, 2011, Pengelolaan Sampah, ITB, Bandung.

KLH, 2008, UURI No No.18/2008 Tentang Pengelolaan Sampah, Jakarta

KepMenLH, 2009, Undang-Undang No. 32 Tahun 2009 Tentang Perlindungan Dan Pengelolaan Lingkungan Hidup, Jakarta.

SNI 03-0691-1996, tentang Bata Beton ( Paving Block).Badan Standardisasi Nasional, 1996 